\title{
HUBUNGAN KEMAMPUAN MERANCANG PERANGKAT PEMBELAJARAN DENGAN KINERJA PRAKTIK MENGAJAR MAHASISWA JURUSAN PENDIDIKAN BIOLOGI
}

\author{
Muh. Rapi ${ }^{1}$, Ahmad Ali ${ }^{2}$ \\ 1,2Fakultas Tarbiyah dan Keguruan UIN Alauddin Makassar \\ 1,2Kampus: Jalan H. M Yasin Limpo No. 36 Samata-Gowa \\ Email: mrapi@uin-alauddin.ac.id ${ }^{1}$
}

\begin{abstract}
Abstrak:
Penelitian ini bertujuan untuk mengetahui gambaran kemampuan merancang perangkat pembelajaran, gambaran kinerja praktik mengajar mahasiswa, dan hubungan antara kemampuan merancang perangkat pembelajaran dengan praktik mengajar mahasiswa Jurusan Pendidikan Pendidikan Biologi yang melaksanakan praktik pengalaman lapangan di Madrasah Aliyah (MA) Madani Paopao Kabupaten Gowa. Jenis penelitian ini merupakan penelitian korelasional. Responden penelitian sebanyak 10 mahasiswa Pendidikan Biologi. Jika dilihat dari tujuan penelitian, maka penelitian ini bersifat evaluatif. Instrumen yang digunakan mengumpulkan data adalah skala penilaian dan lembar observasi. Teknik analisis data menggunakan statistik deskriptif dan statistik inferensial Korelasi Pearson Product Moment. Hasil penelitian menunjukkan 1) kemampuan mahasiswa merancang perangkat pembelajaran dalam kategori baik, 2) kinerja praktik mengajar dalam kategori baik, 3) hubungan antara kemampuan merancang perangkat pembelajaran dengan kinerja praktik mengajar mahasiswa Jurusan Pendidikan Biologi di Madrasah Aliyah (MA) Madani Paopao Kabupaten Gowa dalam kategori kuat.
\end{abstract}

\begin{abstract}
:
This research aims to know the description of the ability to design learning tools, description of the performance of the teaching practice of students, and the relationship between the ability of designing learning tools with the teaching practice of the students of the Biology education Department who conducted teaching practice in Madrasah Aliyah (MA) Madani Paopao Gowa Regency. This research is a correlational research. Research respondents are 10 students of Biology Education department. This research, is evaluative. The instruments used to collect data are assessment scale and observation sheet. Data analysis techniques use descriptive statistics and inferential statistics Pearson Product Moment Correlation. The results showed that 1) the ability of students to design learning tools are in good category, 2) the performance of teaching practice are in good category, 3) the relationship between the ability of designing learning tools with the performance of teaching practice of Biology Education department students at Madrasah Aliyah (MA) Madani Paopao Gowa Regency are in strong category.
\end{abstract}

Kata kunci:

Perangkat Pembelajaran, Kinerja, Praktik Pengalaman Lapangan

PENDIDIK memerlukan keahlian khusus dalam menjalankan tugas profesinya. Guru dan mahasiswa calon guru sebagai pendidik memperoleh keahlian melalui proses 
panjang yang tidak instant. Untuk itu, setiap mahasiswa calon guru wajib mengikuti praktik keguruan yang dikemas dalam matakuliah Praktik Pengalaman Lapangan (PPL) dengan tujuan mempersiapkan calon guru memiliki kompetensi yang kompetitif (Mardiyono, 2006: 58). Keahlian khusus yang dimiliki guru dan calon guru menempatkan dirinya pada posisi penting dan strategis dalam proses pembelajaran dan tidak tergantikan mesin secanggih apapun itu.

Tugas guru dan calon guru menurut Undang-Undang (UU) Republik Indonesia Nomor 20 Tahun 2003 tentang Sistem Pendidikan Nasional pasal 39 ayat 2 dinyatakan "Pendidik merupakan tenaga professional yang bertugas merencanakan dan melaksanakan proses pembelajaran, menilai hasil pembelajaran...". Berdasarkan hal tersebut, guru sebagai tenaga pendidik berkewajiban merancang dan melaksanakan proses pembelajaran secara profesional, sehinggga dalam menjalankan tugas profesionalnya, perangkat pembelajaran menjadi penuntun dalam melaksanakan, menilai dan mengukur keberhasilan proses pembelajaran.

Unsur perencanaan pembelajaran menurut Permendikbud Nomor 65 Tahun 2013 tentang Standar Proses meliputi penyusunan rencana pelaksanaan pembelajaran dan penyiapan media dan sumber belajar, perangkat penilaian pembelajaran, dan skenario pembelajaran. Rancangan pembelajaran pada dasarnya terkait dengan penyiapan dan penyusunan perangkat yang akan dipergunakan dalam proses pembelajaran. Perangkat pembelajaran yang diperlukan dalam mengelola proses belajar mengajar dapat berupa silabus, rencana pelaksanaan pembelajaran (RPP), lembar kegiatan peserta didik (LKPD), instrument evalusai atau tes hasil belajar (THB), media pembelajaran serta buku ajar.

Penyusunan perangkat pembelajaran dan kesiapan berdiri mengajar di depan kelas bagi mahasiswa calon guru atau praktikan, diawali dengan membekali mahasiswa lewat pengajaran matakuliah micro teaching pada semester sebelum praktikan diterjunkan ber-PPL. Berbagai pengetahuan dan keterampilan dasar dibelajarkan dimulai menyusun persiapan mengajar hingga berlatih keterampilan dasar mengajar. Keterampilan dasar mengajar menurut Allen dan Ryan dalam Sukirman meliputi (1) keterampilan membuka, (2) menutup, (3) menjelaskan, (4) mengadakan variasi stimulus, (5) bertanya dasar, (6) bertanya lanjut, (7) balikan dan penguatan, (8) membimbing diskusi, (9) mengajar kelompok kecil dan perorangan, (10) membuat ilustrasi dan contoh dan (11) keterampilan mengelola kelas (Sukirman, 2012: 97).

Rancangan pelaksanaan pembelajaran (RPP) yang disusun mahasiswa dianalisis dan dinilai untuk mengetahui kemampuan merancang perangkat sebelum melakukan pembelajaran dengan kondisi yang sesungguhnya (real teaching). Keberhasilan belajar peserta didik diawali rancangan atau perencanaan pembelajaran yang baik. Menurut Chatib, tujuan rencana pembelajaran akan menggambarkan prosedur, manajemen pembelajaran dan merupakan rencana jangka pendek untuk memperkirakan atau memproyeksikan apa yang akan dilakukan oleh guru dan peserta didik dalam proses pembelajaran (Chatib, 2014: 193).

Mahasiswa jurusan Prodi Pendidikan Biologi Universitas Islam Negeri Alauddin Makassar bertujuan menghasilkan calon guru Biologi. Profil utama lulusan ada- 
lah calon pendidik Biologi pada MTS/SMP/MA/SMA yang berakhlatul karimah, berpengetahuan luas dan mutakhir, berkemampuan dalam melaksanakan tugas profesional berbasis pendekatan integrasi keilmuan, keislaman dan kearifan lokal, serta bertanggung jawab terhadap pelaksanaan tugas berlandaskan etika keilmuan dan profesi.

Salah satu upaya ditempuh mewujudkan profil lulusan tersebut dengan membekali mahasiswa calon guru berpraktik di kelas yang sesungguhnya melalui matakuliah PPL. Adapun perbedaan penelitian ini dengan yang pernah dilakukan sebelumnya yaitu spesifik mengkaji hubungan antara kemampuan merancang perangkat pembelajaran dengan kinerja mengajar mahasiswa calon guru Pendidikan Biologi pada Laboratorium School Fakultas Tarbiyah dan Keguruan Universitas Islam Negeri Alauddin Makassar.

Dari penjelasan dikemukakan di atas, maka rumusan masalah yang diajukan dalam penelitian ini adalah (1) bagaimanakah kemampuan merancang perangkat pembelajaran, (2) bagaimakah kinerja praktik mengajar mahasiswa, dan (3) Adakah hubungan antara kemampuan merancang perangkat pembelajaran dengan praktik mengajar mahasiswa Jurusan Pendidikan Pendidikan Biologi yang melaksanakan praktik pengalaman lapangan di Madrasah Aliyah (MA) Madani Paopao Kabupaten Gowa.

\section{KAJIAN TEORITIS}

\section{Kemampuan}

Gibson dalam Jatiningrum mengungkapkan bahwa kemampuan merupakan sebuah trait (bawaan atau dipelajari) yang menuntun seseorang mengerjakan perbuatan mental atau fisik. Karena itu, kemampuan tidak lain adalah kapasitas seorang individu untuk melaksanakan perbuatan fisik dan mental dalam menyelesaikan pekerjaan (Jatiningrum, dkk., 2016: 118).

Kemampuan didasarkan pengetahuan, keterampilan dan nilai-nilai dasar yang direflesikan dalam kebiasaan berpikir dan bertindak. Kemampuan yang dimikili seseorang yang dinyatakan dalam bentuk tindakan menunjukkan kualitas seorang guru dalam menjalankan tanggung jawab profesionalnya (Sumantri, 2017: 792).

\section{Perencanaan Perangkat Pembelajaran}

Perencanaan berasal dari kata rencana yang berarti pengambilan keputusan tentang apa harus dilakukan untuk mencapai tujuan (Sanjaya, 2011: 22). Jika dikaitkan dengan pembelajaran, maka perencanaan pembelajaran didefinisikan sebagai proses pengambilan keputusan sebagai hasil berpikir secara rasional tentang sasaran dan tujuan pembelajaran tertentu atau perubahan perilaku melalui rangkaian kegiatan dengan memanfaatkan segala potensi dan sumber daya belajar yang ada (Sanjaya, 2011: 28).

Perencanaan pembelajaran merupakan langkah pertama dalam pembelajaran, diwujudkan dalam kegiatan penyusunan RPP. Perencanaan pembelajaran (lesson 
plan) dibedakan atas dua kategori, yaitu perencanaan jangka panjang, dan perencaan jangka pendek (Majid, 2012: 245). Perencanaan jangka panjang disebut unit plan yang merupakan perencanaan yang bersifat komprehensif yang memuat aktivitas guru selama satu semester, sedangkan perencanaan jangka pendek merupakan uraian yang lebih rinci dari unit plan yang disebut persiapan mengajar atau Rencana Pelaksanaan Pembelajaran (RPP). Perencanaan pembelajaran itu sendiri menurut Banghart dan Albert Trull sebagai usaha menggambarkan sifat-sifat aktivitas perencanaan pengajaran yang luas dan mencakup berbagai aktivitas perencanaan dalam sistem pendidikan (Uno, 2010: 4).

Perencanaan pengajaran merupakan suatu program bagaimana mengajarkan apa-apa yang sudah dirumuskan dalam kurikulum. Sagala mengemukakan perencanaan pengajaran (instructional design) dapat dilihat dari berbagai sudut pandang yaitu: (1) Perencanaan pengajaran sebagai sebuah proses; (2) Perencanaan pengajaran sebagai sebuah disiplin; (3) perencanaan pengajaran sebagai sains (science); (4) perencanaan pengajaran sebagai realitas; (5) perencanaan pengajaran sebagai suatu sistem; dan (6) perencanaan pengajaran sebagai teknologi (Sagala, 2011: 136). Perencanaan pembelajaran oleh Arends diwujudkan dalam bentuk catatan-catatan hasil pemikiran awal seorang guru sebelum mengelola proses pembelajaran. Perencanaan pembelajaran merupakan perisapan mengajar yang berisi hal-hal yang perlu atau harus dilakukan oleh guru dan siswa dalam melaksanakan kegiatan pembelajaran yang antara lain meliputi unsur-unsur: pemilihan materi, metode, media, dan alat evaluasi (Arends, 2013: 103).

Rancangan pembelajaran sedianya berpusat pada peserta didik dengan mempertimbangkan karakteristik yang dimilikinya. Oleh karena itu, Davis mengajukan prinsip-prinsip mendesain pembelajaran yaitu; (1) menggunakan metode pembelajaran yang beragam, (2) menampilkan sejumlah cara untuk mengetahui kemampuan peserta didik, (3) menggunakan teknologi informasi, (4) menyediakan pilihan-pilihan untuk partisipasi atau memberikan tugas yang berbeda-beda, dan (5) memberi peluang kepada peserta didik mengerjakan tugas yang berbeda sesuai dengan minat yang dimiliki (Davis, 2013: 4).

Perangkat pembelajaran yang rancang mengelola proses pembelajaran dapat berupa materi ajar, rencana pelaksanaan pembelajaran (RPP) dan lembar kerja siswa (LKS). Pembahasan penelitian hanya difokuskan pada rencana pelaksanaan pembelajaran. Permendikbud Nomor 103 Tahun 2014, dikatakan bahwa hakikat RPP adalah:

... rencana pembelajaran yang dikembangkan secara rinci mengacu pada silabus, buku teks pelajaran, dan buku panduan guru. RPP mencakup: (1) identitas sekolah/madrasah, mata pelajaran, dan kelas/semester; (2) alokasi waktu; (3) KI, KD, indikator pencapaian kompetensi; (4) materi pembelajaran; (5) kegiatan pembelajaran; (6) penilaian; dan (7) media/alat, bahan, dan sumber belajar (Kemendikbud, 2014).

Rencana pelaksanaan pembelajaran (RPP) merupakan komponen penting dari kurikulum berbasis kompetensi termasuk kurikulum 2013. Kurikulum 2013 merupa- 
kan kurikulum berbasis kompetensi yang disempurnakan. Dalam pengembangannya RPP harus dilakukan secara profesional. Tugas pendidik yang paling utama terkait dengan RPP adalah menjabarkan silabus ke dalam RPP yang lebih operasional dan rinci, serta siap dijadikan pedoman atau skenario dalam pembelajaran.

\section{Kinerja}

Kinerja guru merupakan pencapaian prestasi melaksanakan tugas pekerjaannya dalam periode tertentu. Kinerja adalah prestasi kerja, pelaksanaan kerja, pencapaian kerja, hasil kerja atau unjuk kerja (Mulyasa, 2007: 136). Kinerja adalah suatu perbuatan, suatu prestasi atau apa yang diperlihatkan seseorang melalui keterampilan yang nyata (Uno, dkk., 2001: 100). Kinerja guru dapat diukur berdasarkan spesifikasi atau kriteria kompetensi yang harus dimiliki oleh setiap guru. Berkaitan dengan kinerja guru, wujud perilaku yang dimaksud adalah kegiatan guru dalam proses pembelajaran.

Undang-Undang No. 14 Tahun 2005 pada Bab IV Pasal 20 (a) tentang Guru dan Dosen menyatakan bahwa standar prestasi kerja guru dalam melaksanakan tugas keprofesionalannya, guru berkewajiban merencanakan pembelajaran, melaksanakan proses pembelajaran yang bermutu serta menilai dan mengevaluasi hasil pembelajaran. Tugas pokok guru tersebut yang diwujudkan dalam kegiatan merencanakan pembelajaran, melaksanakan pembelajaran dan menilai hasil belajar sebagai bentuk kinerja guru.

Kinerja guru dapat dilihat saat dia melaksanakan interaksi belajar mengajar di kelas termasuk persiapannya baik dalam bentuk program semester maupun persiapan mengajar. Berkenaan indikator mengukur kinerja guru, Sumantri menyarankan aspek (1) kuantitas, jumlah pekerjaan diselesaikan guru, (2) kualitas, mutu pekerjaan guru, dan (3) kelengkapan, kesesuaian alokasi waktu yang direncanakan dengan pencapaian (Sumantri, 2017: 792).

\section{Praktik Pengalaman Lapangan}

Praktik pengalaman lapangan (PPL) merupakan kegiatan kurikuler yang harus dilakukan oleh mahasiswa praktikan, sebagai pelatihan untuk menerapkan teori yang diperoleh dalam bangku perkuliahan. Tujuan pelaksanaan praktik pengalaman lapangan adalah untuk membentuk mahasiswa praktikan agar menjadi calon tenaga kependidikan yang professional, sesuai dengan prinsip-prinsip pendidikan berdasarkan kompetensi, yang meliputi kompetensi pedagogik, kompetensi kepribadian, kompetensi professional, dan kompetensi social (Asril, 2013: 92). PPL dirancang untuk melatih para calon guru menguasai kemampuan keguruan yang utuh dan terintegrasi sehingga setelah menyelesaikan pendidikannya mereka siap secara mandiri mengemban tugas sebagai guru. Kemampuan untuk melaksanakan tugas sebagai guru inilah yang dibentuk melalui PPL. Oleh karena itu, PPL merupakan muara dari seluruh program pendidikan prajabatan guru (Sukirman, 2012: 16).

Secara umum PPL dimaksudkan untuk mempersiapkan calon guru agar menjadi terampil dan professional dalam mengajar. Asril mengemukakan tujuan PPL yaitu 
(1) membimbing calon guru kearah terbentuknya pribadi yang memiliki nilai, sikap pengetahuan dan keterampilan yang dibutuhkan bagi profesi guru, (2) membimbing calon guru agar memiliki kepribadian yang baik dan setia terhadap profesinya, menguasai ilmu serta mampu mengembangkan ilmu-ilmu sesuai bidang ilmunya, dan (3) membimbing calon guru agar menghayati secara apresiatif dan menterampilkan diri dalam semua kegiatan keguruan sehingga terbentuk sikap mental, keterampilan sesuai dengan profesi guru (Asril, 2013: 94).

\section{METODE PENELITIAN}

Jika dilihat hubungan antara variabel, maka jenis penelitian ini merupakan penelitian korelasional. Sedangkan dari segi tujuan maka penelitian ini bersifat evaluatif, yaitu mengevaluasi pelaksanaan program PPL mahasiswa Jurusan Pendidikan Biologi Universitas Islam Negeri Alauddin Makassar. Lokasi penelitian dilaksanakan pada Laboratorium Schools Fakultas Tarbiyah dan Keguruan UIN Alauddin Makassar yaitu Madrasah Aliyah (MA) Madani Paopao Kabupaten Gowa tahun pelajaran 2015/2016. Populasi menurut Arikunto merupakan keseluruhan dari subjek yang diteliti (Arikunto, 2006: 134). Berdasarkan pandangan Arikunto maka subjek dalam penelitian ini adalah seluruh mahasiswa Jurusan Pendidikan Biologi Fakultas Tarbiyah dan Keguruan UIN Alauddin Makassar yang mengikuti PPL. Pengambilan sampel menggunakan menggunakan teknik porvosive sampling, yaitu pengambilan sampel dengan tujuan tertentu untuk mengetahui efektivitas pelaksanaan PPL di Laboratorium Schools Jurusan Pendidikan Biologi. Jumlah mahasiswa PPL di MA Madani Paopao sebanyak 10 orang. Karena jumlah sampel tergolong kecil maka seluruh subjek terpilih sebagai responden. Instrumen penelitian menggunakan rating scale (skala penilaian) untuk menelaah kemampuan merancang perangkat pembelajaran. Sedangkan kinerja mahasiswa dalam mengajar digunakan lembar observasi berbentuk skala yang diamati oleh dua orang guru Biologi saat mahasiswa mengajar.

Data yang terkumpul, dianalisis dengan menggunakan analisis statistic deskriptif dan inferensial. Data kemampuan merancang perangkat pembelajaran dan kinerja praktik mengajar yang terkumpul dibagi menjadi lima kategori, yaitu sangat tinggi, tinggi, sedang, rendah, dan sangat rendah. Untuk mengetahui ada tidaknya hubungan antara kemampuan merancang perangkat pembelajaran dengan kinerja praktik pengalaman lapangan Mahasiswa Jurusan Pendidikan Biologi dianalisis dengan teknik korelasi product moment dengan bantuan software SPSS versi 20 for windows.

\section{HASIL PENELITIAN DAN PEMBAHASAN}

\section{Kemampuan Merancang Perangkat Pembelajaran}

Penelitian tingkat kemampuan merancang perangkat pembelajaran mahasiswa PPL di MA Madani Paopao meliputi aspek penilaian kemampuan (1) merumuskan tujuan pembelajaran, (2) memilih dan mengorganisasikan materi ajar, (3) memilih sumber belajar/media pembelajaran, (4) menyusun skenario/kegiatan pembelajaran, dan (5) penilaian hasil belajar. Hasil penilaian memampuan merancang perangkat pembelajaran dibuat dalam kategori sebagaimana pada tabel 1 sebagai berikut: 
Tabel 1. Kategori Kemampuan Merancang Perangkat Pembelajaran

\begin{tabular}{|c|c|c|c|c|}
\hline No & Nilai & Frekuensi & Kategori & Persentase (\%) \\
\hline 1 & $74-88$ & 1 & Sangat Baik & 10 \\
\hline 2 & $61-73$ & 9 & Baik & 90 \\
\hline 3 & $48-60$ & 0 & Cukup & 0 \\
\hline 4 & $35-47$ & 0 & Sedang & 0 \\
\hline 5 & $22-34$ & 0 & Kurang & 0 \\
\hline \multicolumn{2}{|c|}{ Jumlah } & $\mathbf{1 0}$ & & $\mathbf{1 0 0}$ \\
\hline
\end{tabular}

Berdasarkan data yang diperoleh pada tabel 1 di atas, dengan memperhatikan 10 mahasiswa sebagai responden diketahui bahwa 9 orang $(90 \%)$ berada dalam kategori baik, dan 1 orang (10\%) berada dalam ketegori sangat baik, sehingga tidak ada seorangpun responden yang berada dalam kategori cukup, sedang, ataupun kurang. Sementara itu, jika dilihat dari nilai rata-rata yang diperoleh sebesar 69,1 apabila dimasukkan dalam lima kategori di atas, berada pada interval 61 - 73 dalam kategori baik. Sehingga dapat disimpulkan bahwa kemampuan mahasiswa merancang perangkat pembelajaran berada pada kategori baik.

Berdasarkan perhitungan rata-rata skor penilaian terhadap rencana pelaksanaan pembelajaran yang dibuat diketahui bahwa dari keseluruhan aspek yang dinilai, beberapa aspek menunjukkan skor yang sangat baik, namun beberapa aspek dari rencana pelaksanaan pembelajaran masih memerlukan peningkatan yakni aspek penilaian. Mahasiswa belum mencantumkan teknik penilaian secara lengkap dengan skor maupun kunci jawaban.

Kelemahan dalam hal menentukan bentuk dan jenis penilaian yang sesuai, perlu mendapat perhatian karena penilaian merupakan kegiatan untuk memperoleh, menganalisis, dan menafsirkan data tentang proses dan hasil belajar peserta didik yang dilakukan secara sistematis dan berkesinambungan. Data yang diperoleh akan menjadi informasi yang bermakna dalam pengambilan keputusan oleh pendidik.

\section{Kinerja Praktik Mengajar Mahasiswa PPL}

Kinerja praktik mengajar mahasiswa PPL di MA Madani Paopao Kabupaten Gowa yang dinilai dengan aspek (1) pra pembelajaran seperti kesiapan ruang, alat dan media, (2) membuka pelajaran, (3) penguasaan materi pembelajaran, (4) menggunakan strategi dan metode bervariasi, (6) pemanfaatan media sumber belajar, (7) memicu siswa terlibat aktif mengikuti pembelajaran, (8) menilai proses dan hasil belajar, (9) menggunakan bahasa yang komunikatif, dan (10) menutup/merefleksi pembelajaran.

Berdasarkan data yang diperoleh seperti yang terlihat pada tabel 2, dengan memperhatikan 10 mahasiswa sebagai subjek penelitian dapat diketahui bahwa 4 mahasiswa (40\%) berada dalam kategori cukup, 3 mahasiswa (30\%) berada dalam kategori baik, dan 3 mahasiswa (30\%) berada dalam kategori sangat baik, serta tidak ada seorangpun subjek/responden berada dalam kategori sedang dan kurang. Sementara 
itu, jika dilihat dari nilai rata-rata yang diperoleh sebesar 73,9. Skor tersebut apabila dimasukkan dalam lima kategori maka berada pada interval 67-88. Sehingga dapat disimpulkan bahwa kinerja praktik mengajar mahasiswa PPL di MA Madani Paopao berada pada kategori baik. Hasil kinerja praktik mengajar mahasiswa PPL Jurusan Pendidikan Biologi dibuat dalam bentuk tabel kategori seperti tersaji sebagai berikut:

Tabel 2. Kinerja Praktik Mengajar Mahasiswa PPL di MA Madani Paopao

\begin{tabular}{|c|c|c|c|c|}
\hline No & Nilai & Frekuensi & Kategori & Persentase (\%) \\
\hline 1 & $89-108$ & 3 & Sangat Baik & 30 \\
\hline 2 & $67-88$ & 3 & Baik & 30 \\
\hline 3 & $45-66$ & 4 & Cukup & 40 \\
\hline 4 & $23-44$ & 0 & Sedang & 0 \\
\hline 5 & $0-22$ & 0 & Kurang & 0 \\
\hline \multicolumn{2}{|c|}{ Jumlah } & $\mathbf{1 0}$ & & $\mathbf{1 0 0}$ \\
\hline
\end{tabular}

Berdasarkan perhitungan rata-rata skor penilaian terhadap kinerja praktik pembelajaran diketahui bahwa dari keseluruhan aspek yang dinilai, beberapa aspek menunjukkan skor yang sangat baik seperti pemberian apersepsi, penyampaian tujuan pembelajaran, namun beberapa aspek dari praktik mengajar masih sangat kurang seperti penguasaan kelas, penggunaan media dan sumber belajar, serta metode mengajar yang tidak bervariasi dan dominan menggunakan metode ceramah.

Kelemahan yang ditemukan dalam praktik pembelajaran terutama dalam penggunaan metode pembelajaran yang tidak bervariasi dan kurang sesuai dengan tujuan yang ingin dicapai. Guru yang professional seharusnya dapat mewujudkan suasana belajar dan proses pembelajaran agar peserta didik mencapai kompetensi yang ditetapkan. Pemilihan metode pembelajaran disesuaikan dengan situasi dan kondisi peserta didik, serta karakteristik dari setiap indikator dan kompetensi yang hendak dicapai pada setiap mata pelajaran.

Beberapa kelemahan dalam praktik pembelajaran sejalan dengan penelitian Hapsari dan Widhianningrum menemukan bahwa kemampuan merencanakan pembelajaran seharusnya mendorong mahasiswa calon guru meningkatkan kinerjanya, akan tetapi, menyusunan perencanaan dan mengevaluasi pembelajaran hanya dilaksanakan sebatas kelengkapan saja tanpa adanya pemahaman sehingga mahasiswa calon guru merasa enggan untuk meningkatkan kinerjanya (Hapsari dan Widhianningrum, 2014).

\section{Hubungan antara Kemampuan Merancang Perangkat Pembelajaran dengan Kiner- ja Praktik Mengajar}

Hasil perhitungan statistik inferensial menggunakan uji korelasi product moment diperoleh nilai $r_{\text {hitung }}=0,61$. Interprestasi nilai $r_{\text {hitung }}$ tersebut berdasarkan pedoman interpretasi keeratan hubungan antara kemampuan merancang perangkat pembelajaran dengan kinerja praktik mengajar mahasiswa PPL di MA Madani Paopao adalah kuat. Karena taraf signifikansi yang digunakan $\alpha=0,05(5 \%)$ dan $n=10$, maka diperoleh harga $r_{\text {tabel }}=0,5494$. Ternyata harga $r_{\text {hitung }}$ lebih besar dari harga $r_{\text {tabel, }}$ sehingga Ho 
ditolak dan Ha diterima. Selain itu, diperoleh koefisien determinasi sebesar 37\%. Berdasarkan uji signifikansi di atas diperoleh harga $t_{\text {hitung }}=2,75$. Karena taraf signifikansi yang digunakan $\alpha=0,05(5 \%)$ dan $n=10$, maka diperoleh harga $t_{\text {tabel }}=1,860$. Dimana harga $t_{\text {hitung }}$ lebih besar dari $t_{\text {tabel }}$ sehingga Ho ditolak yang berarti signifikan.

Hasil penelitian ini menunjukkan bahwa kemampuan merancang perangkat pembelajaran berhubungan secara signifikan dengan kemampuan mahasiswa dalam menerapkan rancangan pembelajaran yang telah disusun meskipun dalam kenyataannya, berdasarkan hasil observasi masih terdapat beberapa kekurangan dalam pelaksanaan pembelajaran yang perlu ditingkatkan. Hasil penelitian ini sejalan dengan temuan Choirul Huda \& Udik Yudiono yaitu (1) Kemampuan mahasiswa dalam mempersiapkan pembelajaran sudah cukup baik dengan rerata nilai sebesar 75,6; (2) Kemampuan mahasiswa dalam melaksanakan pembelajaran sudah cukup baik dengan rerata nilai sebesar 75,9 (Huda dan Yudiono, 2013). Temuan ini sejalan pula dengan penelitian Afan Hardiansyah yang menyimpulkan mahasiswa memperoleh nilai microteaching A mempunyai kesiapan cukup baik melaksanakan PPL, nilai microteaching A- kesiapan kurang baik, nilai microteaching B+ kesiapan baik, dan mahasiswa dengan nilai microteaching B mempunyai kesiapan kurang baik dalam melaksanakan PP (Hardiansyah, 2017).

\section{SIMPULAN DAN SARAN}

Berdasarkan hasil penelitian diperoleh kesimpulan sebagai berikut:

1. Kemampuan mahasiswa pendidikan Biologi merancang perangkat pembelajaran termasuk dalam kategori baik dengan rata-rata 69,1 pada interval skor 61-73.

2. Kinerja mahasiswa pendidikan Biologi melakukan kegiatan praktik mengajar termasuk dalam kategori baik dengan rata-rata 73,9 pada interval skor 67-88.

3. Kemampuan mahasiswa pendidikan Biologi merancang perangkat pembelajaran memiliki hubungan yang kuat dengan kinerja praktik mengajar, ditandai koefisien korelasi 0,61 dengan determinasi $37 \%$ serta signifikansi uji $t_{\text {hitung }}=2,75>t_{\text {tabel }}=$ 1,86 .

Mahasiswa calon guru harus terus melatih diri untuk meningkatkan kemampuan merancang perangkat pembelajaran terutama pada aspek penilaian, dengan berlatih menyusun penilaian secara lengkap disertai skor/rubrik maupun kunci jawaban. Demikian halnya dengan kinerja praktik mengajar agar terus melatih diri agar kemampuan meningkat dalam penguasaan materi, penguasaan kelas, penggunaan media dan sumber belajar, serta menggunakan metode mengajar yang bervariasi. Khusus pengelola Jurusan agar meningkatkan capaian pembelajaran mata kuliah yang mendukung kemampuan praktik mengajar mahasiswa calon guru.

\section{DAFTAR PUSTAKA}

Arends, R. I. (2013). Belajar Untuk Mengajar (Learning to Teach), Edisi 9 Buku 1; Jakarta: Salemba Humanika.

Arikunto, S. (2006) Prosedur Pebelitian: Suatu Pendekatan Praktik, Cet. XIII; Jakarta: PT. Rineka Cipta. 
Asril, Z. (2013). Micro Teaching; Disertai dengan Pedoman Pengalaman Lapangan, Cet. V; Jakarta: Rajawali Press.

Chatib, M. (2014). Gurunya Manusia, Cet. XV; Bandung: Penerbit Kaifa.

Davis. (2013). Barbara Gross, Tools for Teaching diterjemahkan Elok Dianike Perangkat Pembelajaran: Teknik Mempersiapkan dan Melaksanakan Pembelajaran yang Efektif, Cet. I; Jakarta: Rajagrapindo Persada.

Hapsari, P., \& Purweni. W. (2014). “Pengaruh Praktik Pengalaman Lapangan terhadap Kinerja Mahasiswa Calon Guru", Journal of Accounting and Bussiness Education, Vol. 2, No. 1, Maret 2014, http://journal.um.ac.id/index.php/jabe/article/view/6050. Diakses 4 Agustus 2017.

Hardiansyah, A. (2017). “Kesiapan Mahasiswa Program Studi Pendidikan IPS untuk Melaksanakan PPP dan Faktor-faktor yang Mempengaruhinya", Journal Social Studies, Vol. 6 No. 7 (2017), http://journal.student.uny.ac.id/ojs/ojs/index.php/social-studies/article/view/10192/9756.

Huda, C., \& Udik, Y. (2013). “Analisis Kinerja Mahasiswa Peserta PPL FKIP Universitas Kanjuruhan Malang", Jurnal Inspirasi Pendidikan, Vol. 3, No. 2 (2013), http://ejournal.unikama.ac.id/ index.php/jrnspirasi/article/view/483.

Jatiningrum, C. D., dkk. (2016). "Pengaruh Budaya Organisasi, Motivasi dan Kemampuan terhadap Kinerja (Studi Pada Karyawan dan Agen PT Asuransi Jiwasraya Branch Office Malang)", Jurnal Administrasi Bisnis, Vol. 39. No. 1 (2016). Diakses 6 Agustus 2017.

Kementerian Pendidikan dan Kebudayaan. (2014). Peraturan Menteri Pendidikan dan Kebudayaan No. 103 Tahun 2014 Tentang Pembelajaran pada Pendidikan Dasar dan Menengah. Jakarta: Direktorat Pendidikan Dasar dan Menengah.

Majid, A. (2012). Perencanaan Pembelajaran; Mengembangkan Standar Kompetensi Guru. Bandung: Rosda Karya.

Mardiyono, S. (2006). "Praktik Pengalaman Lapangan Terpadu dalam Peningkatan Kualitas Calon Guru", Jurnal Cakrawala Pendidikan, Februari 2006, Th. XXV, No. 1.

Mulyasa, E. (2007). Standar Kompetensi dan Sertifikasi Guru. Bandung: Rosdakarya.

Republik Indonesia. (2009). Undang-Undang No. 20 Tahun 2003 Tentang Sistem Pendidikan Nasional. Cet. II; Jakarta: Sinar Grafika.

Republik Indonesia. (2009). Undang-Undang No.14 Tahun 2005 Tentang Guru dan Dosen. Cet. II; Jakarta: Sinar Grafika.

Republik Indonesia. (2013). Peraturan Menteri Pendidikan dan Kebudayaan Nomor 65 Tahun 2013 tentang Standar Proses. Jakarta: Depdikbud.

Sagala, S. (2011). Konsep dan Makna Pembelajaran, Cet. IX; Bandung Alfabeta.

Sanjaya, W. (2011). Strategi Pembelajaran Berorientasi Standar Proses Pendidikan, Cet. 8; Jakarta: Kencana Penada Media.

Sukirman, D. (2012). Pembelajaran Micro Teaching, Cet. 2; Jakarta: Direktorat Pendidikan Islam Kementerian Agama RI.

Sumantri, B. "Pengaruh Kemampuan, Motivasi dan Semangat Kerja Terhadap Kinerja Guru SMP Negeri di Balongpanggang", Jurnal Mitra Pendidikan, Volume 1, Nomor 7, September 2017, http:/ /e-jurnalmitrapendidikan.com/index.php/e-jmp/article/ view/176/73. Diakses 5 Agustus 2017.

Uno, H. B., dkk. (2001). Pengembangan Instrumen Penelitian. Jakarta: Delima Press.

Uno, H. B., dkk. (2010). Desain Pembelajaran, Jakarta: MQS Publishing. 